\title{
Organizational Citizenship Behaviors and Relationship to Internal Marketing of Nursing Profession
}

\author{
Magda Abd El Baest Mohamed ${ }^{1}$, Gehan M. Diab ${ }^{2}$, Soha M. El-Kholy ${ }^{3}$ \\ ${ }^{1}$ B.SC in nursing sciences, ${ }^{2}$ professor of Nursing Administration, ${ }^{3}$ lecturer of Nursing \\ Administration, Faculty of Nursing, Menoufia University,
}

\begin{abstract}
Background: Due to their important roles in organizational performance, internal marketing and organizational citizenship behavior have become more interesting subjects among researchers and practitioners. The purpose of this study: Was to assess the relationship between organizational citizenship behavior and internal marketing of nursing profession. Research design: A descriptive correlational research design was utilized. Setting: The study was conducted at Menoufia University Hospitals at Shebin El- Kom. Sample: systematic random sample of 400 staff nursing was included in the study. Instruments: Two instruments were used to collect data. First instrument: Internal marketing questionnaire .Second instrument: Organizational Citizenship behavior Scale. Results: Nearly two thirds $(63.3 \%)$ of the staff nurses had high level of total organizational citizenship behaviors, $57.2 \%$ of staff nurses reported high level of internal marketing. There was a significant positive correlation between organizational citizenship behaviors and internal marketing of nursing profession. Recommendation: Menoufia University hospitals should provide more care to internal marketing activities, and direct more organizations' resources and capabilities towards benefiting their employee as much as possible and encourage tools that increase the citizenship behavior.
\end{abstract}

Keywords: Internal marketing, Nursing profession, Organizational citizenship behaviors.

\section{Introduction}

Health care organizations today are facing frequent developments and technological changes that need to be adopted with financial and human resource capital. A permanent lack of organizational resources and funding available to the healthcare sector has resulted in downsizing, restructuring and increased job complexity that put the organization in a great challenge to be open to change, team-oriented, proactive and learning organizations and manage human resources to get the staff nurses to be assigned more work than the prescribed job description and contribute extra efforts manifested by organizational citizenship behavior 


\section{Profession}

among all staff nurses in the health care organizations that are encouraged to structurally empower the employees so that a sense of worth could be created in all employees (Kasekende, Nasiima \& Otengei, 2020).

Organizational citizenship behavior is a contribution that exceeds the role demands of an individual in the workplace, it involves behaviors like helping others, volunteering for extra duties, while adhering to the rules and procedures in the workplace. These behaviors describe "employee added value," which is a form of prosocial behavior that is described as displaying positive social behavior, and offering constructive and meaningful help, also organizational citizenship behavior is individuals' free behavior that is not directly or explicitly associated with a reward system that could increase effective functioning in the organization (Titisari, Afandi \& Lukiyanto, 2020).

Organizational citizenship behaviors (OCBs) are vital for continuous organizational growth and development, also play an evident role in advancing the quality of health care services and facilities. It is also, required especially in the hospital because patients need special care and positive behaviors of health personnel in handling the patients' cases and has an important role in improving patients' care and morale, facilitate access to health care organizations goals and enhance its performance. Also, OCBs have been shown to have a considerable positive impact at the organizational level, increase productivity, efficiency, reduce costs and rates of staff turnover and absenteeism thus enhancing organizational effectiveness (Chamisa, Mjoli, \& Mhlanga, 2020).

Successful nurse managers attempt to persuade staff nurses to emerge voluntary behaviors named organizational citizenship behaviors for the organizations in order to strengthen the responsibility and empower the human resources. In other words, motivating the human resources for empowering them to emerge the organizational citizenship behaviors will be a great challenge of current nurse managers (Griffin et al., 2020).

Internal marketing is perceived as a philosophy where employees are regarded as an organization's internal customers and are treated as such. As a strategy, internal marketing is geared towards the attraction, 


\section{Profession}

development, retention and inter-

functional coordination of employees, with the objective of enhancing employee satisfaction while creating service quality and satisfaction for the external customer. Also IM enhances the productivity of the employees and patient safety which increases salaries. This is important for the public non-profit healthcare system because increased employees' satisfaction help the hospital to treat a greater number of patients, will increase the hospital funds (Yeum, Wee \& Bang, 2020).

Marketing is a total system of interactional activities in an organization designed to plan, price, promote and distribute need satisfying products to existing and potential consumers. That is highly influenced by quality management and service marketing that emphasizes on importance and necessity of creating quality in all processes of providing services, this area of marketing considers the relationship between customers and internal suppliers of organization in order to make value for external customers (Gabbianelli \& Pencarelli, 2021).

This can appear as a chain of value and tools to develop quality of products, services and interaction inside and outside of organization. Thus, the goal of internal marketing is to ensure the satisfaction of employees and consequently efforts to develop the quality of products and services to achieve the satisfaction of external customers. The activities involved in internal marketing include training employees, empowerment, knowing Employees needs good internal communication and measuring and rewarding quality. Internal marketing look at the employees as internal customers and work as internal products. The logic of this concept is that an organization will have better status to provide high quality services to meet the needs of external customers by meeting needs of internal customers (De Bruin, RobertsLombard \& De Meyer-Heydenrych, 2020).

Internal marketing management practices are a great way to increase creativity within organizations. It is also an attractive system for employees, because it plays an active role in their collaboration, commitment, interaction and contributing in real creativity and knowledge, that will help in leading to an optimal citizenship behavior, as 


\section{Profession}

well as contributes in achieving the organization's goals and sustainability. Employees as internal customers have to be satisfied with their job first before they can satisfy the customers of the organization. Therefore, it is necessary to study the internal marketing management practices in organizations that have created a fertile environment which can find new ideas in order to reach the desired goals, and their impact on the safety of achieving employees' objectives in particular, and their reputation in the local market in general (Boonparn, Rurkwararuk, Pooncharoen \& Leamprecha, 2020).

\section{Significance of the study:}

Today intense competition in health care environment needs induction and diversion of values added to heath service customer such as internal marketing activities and organizational citizenship behavior which enable nurses to provide health service with high quality and increasing hospital productivity and profitability. Due to nurses' important roles in organizational performance, internal marketing and organizational citizenship behavior have become more interesting subjects among researchers and practitioners (Ali, 2017; Yildiz \& Suleyman; 2016
Ozturk, 2010). Therefore, the current study will be conducted to assess the relationship between organizational citizenship behavior and internal marketing of nursing profession at Menoufia University Hospital.

\section{Purpose of the Study:}

The main purpose of this study was to assess the relationship between organizational citizenship behavior and internal marketing of nursing profession at Menoufia University Hospitals at Shebin El-Kom.

\section{Research questions:}

1) What is the perception of staff nurses regarding organizational citizenship behavior?

2) What is the availability of utilization of internal marketing elements among staff nurses?

3) Is there a relationship between organizational citizenship behavior and internal marketing of nursing profession?

\section{Methods}

\section{Research Design}

A descriptive correlational research design was used for conducting this study

\section{Setting}

The study will be conducted at Menoufia University Hospitals at 


\section{Profession}

Shebin El- Kom which was established in 1993. Menoufia University Hospitals contains four buildings as follow: Main university Hospital, Emergency Hospital, Specialized Hospital, and Oncology institute. This hospital includes 1200 staff nurses are distributed as 800 in critical care units 400 in other departments and 92 head nurse.

\section{Sample}

Health care is at Menoufia university hospitals provided by 1200 nurses are distributed into 800 nurses in critical care units 400 in medical departments and 92 head nurse (statistical Administrative Records of Hospitals, 2018). The total number of nurses to be selected was estimated using the following equation:

$$
n_{r}=\frac{4 p q}{d^{2}}
$$

Where $\mathrm{nr}=$ required sample size, $\mathrm{p}=$ proportion of the staff nursing having the perception of organizational citizenship behavior, $\mathrm{q}=1-\mathrm{p}$ and $\mathrm{d}=$ the degree of precision. As the proportion of the staff nurses (p) is unknown, the researchers used $p=0.5$ which assumes maximum heterogeneity (i.e. a 50/50 split). The degree of precision (d) is the margin of error that is acceptable $(d=0.05)$.

$$
n=\frac{4 p q}{d^{2}}=\frac{4 \times 0.5 \times 0.5}{0.05^{2}}=\frac{1}{0.0025}=400
$$

Accordingly, our total sample size was 400 staff nurses working at Menoufia University Hospitals.

\section{Instruments:}

Two instruments were used to collect data

\section{Instrument one: Internal marketing questionnaire:}

It was developed by Khtab, (2014) and adapted by the investigator to assess the availability of utilization of internal marketing elements among staff nurses. It consists of two parts:

Part one: This part consists of seven questions to collect data related to social characteristics of staff nurses. These questions were age, educational qualification, marital status, department, years of experience, and years of experience in the current department and work hours.

Part two: This part consists of 73 items (a three-point Likert scale). This questionnaire was subdivided into nine interrelated internal marketing parts 
namely:(Employee-oriented behaviors, Communication management, Employee training, Job description, fair reward, Organizational support, Supervisor support, Empowerment, Employment security).

Scoring system; the responses were rated on a three point Likert scale ranging from 3: frequently utilized, 2 : sometimes utilized 1, rarely utilized. The total possible score for the items of the questionnaire ranged from 73 to 215. Scores of each element summed up and converted into percent. The level of the availability of utilization of internal marketing was high if the percent score more than $75 \%$, moderate if the percent score ranged from $60 \%-75 \%$ and low in less than $60 \%$. Cronbach's $\alpha$ value for the instrument is (0.915).

\section{Instrument two: Organizational Citizenship behavior Scale:}

This scale was developed by LePine, Erez \& Johnson, (2002) and modified by the investigator. The scale will be used to assess nurses' perception of organizational citizenship behavior and consists of 24 items using a three point Likert scale. This questionnaire was subdivided into five dimensions of :( Altruism, generalized compliance, civic virtue, courtesy, and sportsmanship).

Scoring system; the responses was based on three points Likert scale ranging from 3, usually, 2 sometimes and 1 rarely. The total possible score for the items of the questionnaire ranged from 24 to 72 . Scores of each element summed up and converted into percent. The nurses' perception of organizational citizenship behavior was high if the percent score more than $75 \%$,moderate if the percent score ranged from $60 \%-75 \%$ and low in less than $60 \%$. Cronbach's $\alpha$ of the overall OCB $(\alpha=0.757)$ and Cronbach's $\alpha$ for the 5 subscales ranges from $(0.663$ to $0.802)$.

\section{Validity of the instruments}

A committee that was composed of 5 experts in administration were selected to share (3 professors and 2 Assistant Professors) in judging the instrument. The needed modifications based on jury's opinions were done by the investigator.

\section{Ethical considerations}

Approval was obtained from the Ethics Committee of the Faculty of Nursing, Menoufia University. The privacy and confidentiality of data were maintained and assured by 


\section{Profession}

getting participants' consent to participate in the research before data collection. Anonymity of participants was granted.

\section{Statistical analysis}

Data was coded and transformed into specially designed form to be suitable for computer entry process. Data was entered and analyzed by using SPSS (Statistical Package for Social Science) statistical package version 19. Graphics were done using Excel program.
Quantitative data were expressed as mean \& standard deviation $(\mathrm{X} \pm \mathrm{SD})$. Qualitative data were expressed as number and percentage (No \& \%). Pearson correlation coefficient calculated between the study variables.

\section{$P$-value at 0.05 was used to determine} significance regarding:

- P-value >0.05 to be statistically insignificant.

- P-value $\leq 0.05$ to be statistically significant.

- P-value $\leq 0.001$ to be high statistically significant.

\section{Results}

Table (1): Social characteristics of the studied staff nurses $(\mathrm{N}=400)$ :

\begin{tabular}{|c|c|c|}
\hline social characteristics & No. & $\%$ \\
\hline $\begin{array}{l}\text { Age / years } \\
<33 \text { years } \\
\geq 33 \text { years }\end{array}$ & $\begin{array}{l}202 \\
198\end{array}$ & $\begin{array}{l}50.5 \\
49.5\end{array}$ \\
\hline $\begin{array}{l}\text { Range } \\
\text { Mean } \pm \text { SD }\end{array}$ & \multicolumn{2}{|c|}{$\begin{array}{c}20-35 \\
32.3 \pm 2.83\end{array}$} \\
\hline $\begin{array}{l}\text { Marital state } \\
\text { Married } \\
\text { Not married }\end{array}$ & $\begin{array}{c}353 \\
47\end{array}$ & $\begin{array}{l}88.3 \\
11.7\end{array}$ \\
\hline $\begin{array}{l}\text { Educational level } \\
\text { Nursing school diploma degree. } \\
\text { Associated degree in nursing. } \\
\text { Bachelor degree in nursing. } \\
\text { Post graduate. }\end{array}$ & $\begin{array}{c}12 \\
41 \\
320 \\
27\end{array}$ & $\begin{array}{c}3.0 \\
10.3 \\
80.0 \\
6.7\end{array}$ \\
\hline $\begin{array}{l}\text { Years of experience } \\
(1-5 \text { years }) \\
(6-10 \text { years }) \\
(11-20 \text { years })\end{array}$ & $\begin{array}{c}57 \\
175 \\
168\end{array}$ & $\begin{array}{l}14.2 \\
43.8 \\
42.0\end{array}$ \\
\hline $\begin{array}{l}\text { Years of experience in the current department } \\
(1-5 \text { years }) \\
(6-10 \text { years }) \\
(11-20 \text { years })\end{array}$ & $\begin{array}{c}170 \\
192 \\
38\end{array}$ & $\begin{array}{l}42.5 \\
48.0 \\
9.50\end{array}$ \\
\hline $\begin{array}{l}\text { Work hours } \\
6 \text { hours } \\
12 \text { hours }\end{array}$ & $\begin{array}{c}352 \\
48 \\
\end{array}$ & $\begin{array}{l}88.0 \\
12.0 \\
\end{array}$ \\
\hline
\end{tabular}




\section{Profession}

Table (1) shows social characteristics of staff nurses. As shown in this table approximately half of nurses $(50.5 \%)$ were less than 33 years, As regards marital status the majority (88.2\%) of staff nurses were married. The highest percentage $(80 \%)$ of them had bachelor degree in nursing. Regarding years of experience, nearly half $(43.8 \%)$ of staff nurses had 6 to 10 years of experience. Furthermore, less than half $(48.0 \%)$ of them had 6 to 10 years of experience in the current department. The majority $(88 \%)$ of staff nurses were working 6 hours/day.

Table (2): Mean and standard deviation of adherence to organizational citizenship behaviors among the studied staff nurses

\begin{tabular}{|l|c|c|c|}
\hline \multirow{2}{*}{\multicolumn{1}{|c|}{ Studied variables }} & \multicolumn{2}{c|}{ Range } & \multirow{2}{*}{ Mean \pm SD } \\
\cline { 2 - 3 } & Min & Max & $12.6 \pm 2.63$ \\
\hline Altruism & 5 & 15 & $12.7 \pm 0.94$ \\
\hline Generalized compliance & 5 & 15 & $8.49 \pm 2.17$ \\
\hline Civic virtue & 4 & 12 & $13.5 \pm 1.23$ \\
\hline Courtesy & 5 & 15 & $7.06 \pm 2.06$ \\
\hline Sportsmanship & 5 & 15 & $54.3 \pm 8.33$ \\
\hline Total OCB & 24 & 72 & 1 the \\
\hline
\end{tabular}

This table illustrates the total mean and $(13.5 \pm 1.23) \quad$ while the lowest standard deviation of adherence to organizational citizenship behaviors. It showed that the highest organizational citizenship behavior was courtesy organizational citizenship behavior was sportsmanship with (7.06 \pm 2.06$)$. The total organizational citizenship behaviors mean was $(54.3 \pm 8.33)$.

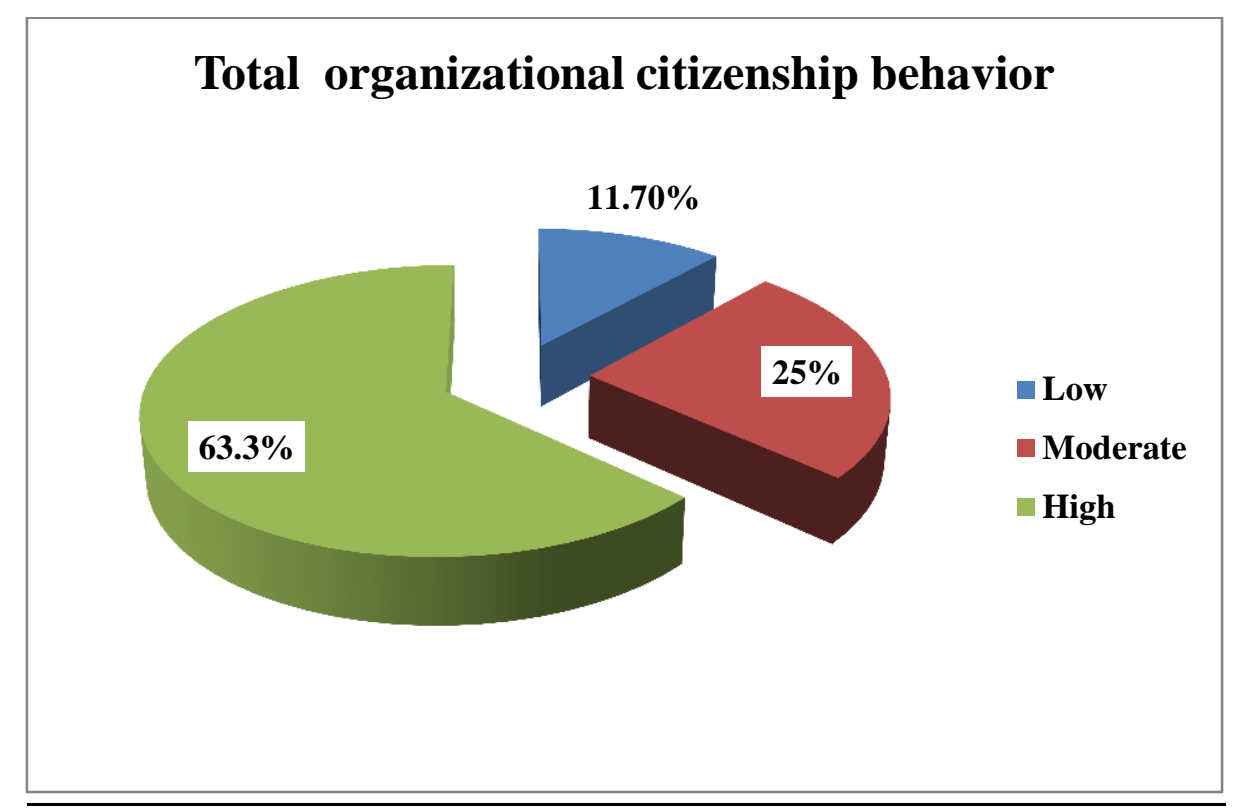

Figure (1): Percentage distribution of nurses' adherence to_organizational citizenship behaviors 
Figure1.Illustrates percentage distribution of nurses' adherence to organizational citizenship behaviors .It showed that nearly two thirds of staff nurses $(63.3 \%)$ had a high level of total organizational citizenship behaviors, while there was minimum percent (only, 11.70\%) of them had a low level of organizational citizenship behaviors and more than one fifth $(25 \%)$ of the staff nurses had a moderate level of organizational citizenship behaviors.

Table (3): Mean and standard deviation of adherence to internal marketing behaviors

\begin{tabular}{|l|c|c|c|}
\hline \multirow{2}{*}{\multicolumn{1}{|c|}{ Studied variables }} & \multicolumn{2}{c|}{ Range } & \multirow{2}{*}{ Mean \pm SD } \\
\cline { 2 - 3 } & Min & Max & \\
\hline Employees- oriented behavior & 7 & 21 & $16.4 \pm 3.76$ \\
\hline Communication management & 6 & 18 & $15.5 \pm 3.20$ \\
\hline Employee training & 7 & 21 & $17.6 \pm 3.34$ \\
\hline Job description & 8 & 24 & $21.6 \pm 4.72$ \\
\hline Fair reward & 11 & 33 & $24.1 \pm 4.72$ \\
\hline Organizational support & 5 & 15 & $9.07 \pm 2.46$ \\
\hline Supervisor support & 15 & 45 & $35.6 \pm 6.64$ \\
\hline Empowerment & 4 & 12 & $8.01 \pm 2.19$ \\
\hline Employments security & 9 & 27 & $19.9 \pm 4.04$ \\
\hline Total internal marketing & 73 & 219 & $168.2 \pm 33.8$ \\
\hline
\end{tabular}

This table illustrates the total mean of

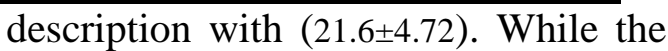
internal marketing and its sub dimensions among staff nurses. It lowest internal marketing dimension is organizational support with $(9.07 \pm 2.46$ showed that the highest internal marketing dimension was job

).The total internal marketing mean was $(168.2 \pm 33.8)$.

\section{Total internal marketing}

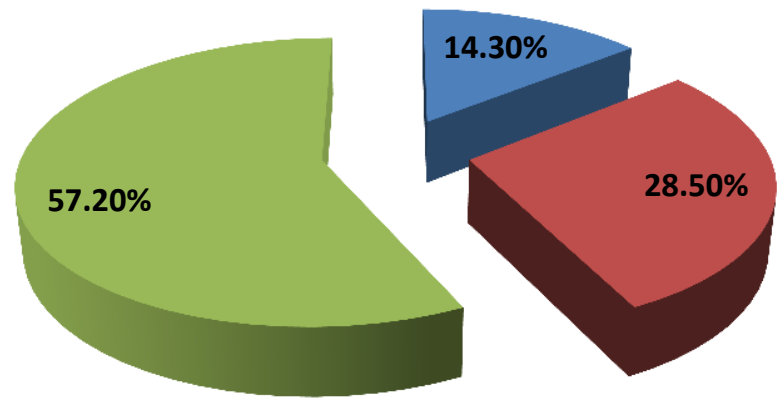

Low

Moderate

High

Figure (2): percentage distribution of staff nurses according to their perception of utilization of internal marketing elements among the studied nurses 
Figure (2): Illustrates percentage distribution of staff nurses according to their perception of utilization of internal marketing elements among the studied nurses. It showed that the highest percentage $(57.2 \%)$ of studied nurses reported a high level of internal marketing. While, minority (14.3\%) of them reported a low level of internal marketing, and nearly one third (28.5\%) of them noted a moderate level of internal marketing.

Table (4): Correlation coefficient ( $\mathrm{r}$ ) between organizational citizenship behavior dimensions and internal marketing dimensions among the studied nurses $(n=400)$ :

\begin{tabular}{|c|c|c|c|c|c|c|c|}
\hline \multirow{2}{*}{\multicolumn{2}{|c|}{ Internal marketing }} & \multicolumn{6}{|c|}{ Organizational citizenship behavior } \\
\hline & & \multirow{2}{*}{$\begin{array}{c}\text { Altruism } \\
-0.092 \\
\end{array}$} & \multirow{2}{*}{$\begin{array}{c}\text { Generalized } \\
\text { compliance }\end{array}$} & \multirow{2}{*}{$\begin{array}{c}\begin{array}{c}\text { Civic } \\
\text { virtue }\end{array} \\
-0.143 \\
\end{array}$} & \multirow{2}{*}{$\begin{array}{c}\text { Courtesy } \\
-0.175 \\
\end{array}$} & \multirow{2}{*}{$\begin{array}{c}\text { Sportsmanship } \\
0.314 \\
\end{array}$} & \multirow{2}{*}{$\begin{array}{l}\text { Total } \\
0.024 \\
\end{array}$} \\
\hline Employees- & $\mathbf{r}$ & & & & & & \\
\hline oriented behavior & $P$ value & 0.065 & 0.561 & $0.004 * *$ & $0.001 * *$ & $0.001 * *$ & 0.626 \\
\hline \multirow{2}{*}{$\begin{array}{l}\text { Communication } \\
\text { management }\end{array}$} & $\mathbf{r}$ & -0.162 & -0.243 & 0.056 & -0.024 & 0.222 & 0.004 \\
\hline & P value & $0.001 * *$ & $0.001 * *$ & 0.260 & 0.643 & $0.001 * *$ & 0.930 \\
\hline \multirow{2}{*}{ Employee training } & $\mathbf{r}$ & 0.085 & 0.337 & -0.259 & 0.052 & -0.067 & -0.055 \\
\hline & P value & 0.088 & $0.001 * *$ & $0.001 * *$ & 0.299 & 0.182 & 0.268 \\
\hline \multirow{2}{*}{ Job description } & $\mathbf{r}$ & 0.046 & -0.223 & 0.055 & 0.321 & 0.193 & 0.123 \\
\hline & P value & 0.360 & $0.001 * *$ & 0.271 & $0.001 * *$ & $0.001 * *$ & 0.014* \\
\hline \multirow{2}{*}{ Fair reward } & $\mathbf{r}$ & -0.261 & 0.054 & -0.291 & -0.140 & -0.135 & 0.249 \\
\hline & $P$ value & $0.001 * *$ & 0.278 & $0.001 * *$ & $0.005 * *$ & $0.007 * *$ & $0.001 * *$ \\
\hline \multirow{2}{*}{$\begin{array}{l}\text { Organizational } \\
\text { support }\end{array}$} & $\mathbf{r}$ & -0.471 & -0.017 & -0.187 & 0.077 & 0.282 & -0.094 \\
\hline & P value & $0.001 * *$ & 0.736 & $0.001 * *$ & 0.125 & $0.001 * *$ & 0.060 \\
\hline \multirow{2}{*}{$\begin{array}{l}\text { Supervisor } \\
\text { support }\end{array}$} & $\mathbf{r}$ & -0.009 & 0.023 & 0.081 & -0.110 & 0.519 & 0.285 \\
\hline & $P$ value & 0.857 & 0.644 & 0.105 & $0.027 *$ & $0.001 * *$ & $0.001 * *$ \\
\hline \multirow{2}{*}{ Empowerment } & $\mathbf{r}$ & 0.134 & -0.240 & 0.495 & 0.077 & 0.122 & 0.370 \\
\hline & $P$ value & $0.007 * *$ & $0.001 * *$ & $0.001 * *$ & 0.124 & $0.015^{*}$ & $0.001 * *$ \\
\hline \multirow{2}{*}{$\begin{array}{l}\text { Employment } \\
\text { security }\end{array}$} & $\mathbf{r}$ & 0.034 & -0.022 & 0.175 & -0.322 & -0.243 & -0.033 \\
\hline & $P$ value & 0.494 & 0.661 & $0.001 * *$ & $0.001 * *$ & $0.001 * *$ & 0.515 \\
\hline
\end{tabular}

Significance level at $\mathrm{p}$ value $<0.05 * *$ High significant

This table shows the correlation coefficient between organizational citizenship behavior dimensions and internal marketing dimensions among the studied nurses. It clarified that there was a significant positive correlation between organizational citizenship behavior and job description $(\mathrm{r}=0.123$, $\mathrm{p}=0.014)$ fair reward $\quad(\mathrm{r}=0.249$, $\mathrm{p}=0.001)$, supervisor support $(\mathrm{r}=0.285$, $\mathrm{p}=0.001)$ and empowerment $(\mathrm{r}=0.370$, $\mathrm{p}=0.001)$.On the other hand there was no significant correlation between organizational citizenship behavior and employees-oriented behavior, communication management, employee training, organizational support and employment security $(\mathrm{p}>0.05)$. 


\section{Profession}

Table (5): Pearson Correlation between total organizational citizenship behavior and internal marketing of nursing profession $(n=400)$ :

\begin{tabular}{|l|c|c|}
\hline \multirow{2}{*}{ Variables } & \multicolumn{2}{|c|}{ Organizational citizenship behavior } \\
\cline { 2 - 3 } & $\mathbf{r}$ & P value \\
\hline Internal marketing & 0.785 & $\mathbf{0 . 0 0 1} * *$ \\
\hline
\end{tabular}

Significance level at $\mathrm{p}$ value $<0.001 * *$ High significant

This table shows the correlation positive correlation between between total organizational citizenship behavior and total internal marketing among the studied nurses .It organizational citizenship behaviors and total internal marketing of nursing profession $(\mathrm{r}=0.785, \mathrm{p}=0.001)$. clarified that there was a significant

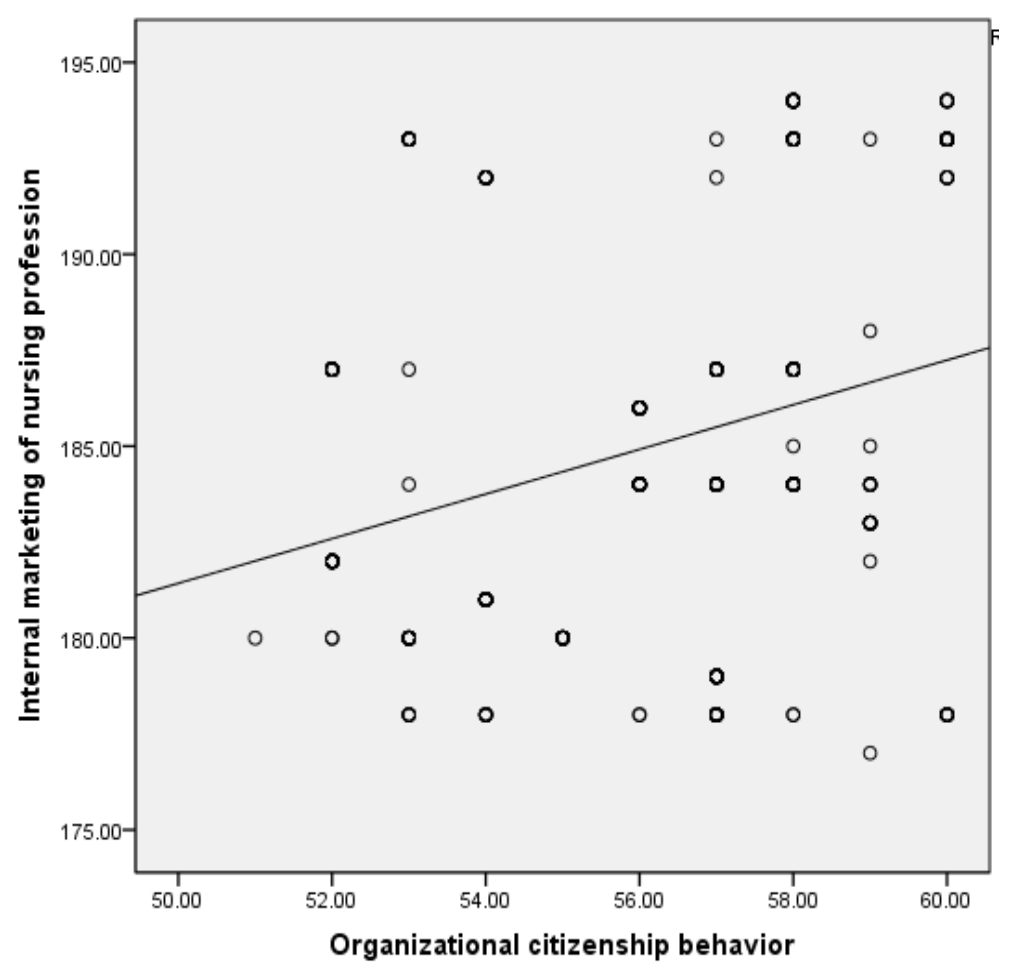

Figure (3): Correlation between total organizational citizenship behavior and internal marketing of nursing profession.

\section{DISCUSSION}

One of the major factors that help in gaining a competitive advantage, and create sustainable value for organizations is caring for human resources. Internal marketing is an approach that treats employees as the most valuable asset; and leads to satisfying internal customer's needs (Kryscynski, Coff \& Campbell, 2021). 


\section{Profession}

Organizational citizenship behavior is a desirable trait for health care organizations because of the development of important job satisfaction and organizational productivity. In general, OCBs are found to be important in promoting a higher level of organizational productivity, quality, and effectiveness (Abdulmuhsin, Zaker \& Asad, 2021).

Adoption of internal marketing practices and techniques has an effect on citizenship behavior and employee retention. This improves their in-role and extra-role behaviors. So, internal marketing influences organizational citizenship behavior which eventually has an impact on the performance of the organization in total (Boonparn, Rurkwararuk, Pooncharoen \& Leamprecha, 2020).

Thus, this study was conducted to assess organizational citizenship behaviors and their relationship to internal marketing of nursing profession as perceived by staff nurses in Menoufia University Hospitals through answering the following questions; the $1^{\text {st }}$ question was "What is the perception of staff nurses regarding organizational citizenship behavior?" the $2^{\text {nd }}$ question was "What is the availability of utilization of internal marketing elements among staff nurses? , and finally the $3^{\text {rd }}$ question was "Is there a relationship between organizational citizenship behavior and internal marketing of nursing profession?

For total mean and standard deviation of adherence to organizational citizenship behaviors perceived by staff nurses. The present study showed that the highest organizational citizenship behavior was courtesy, while the lowest organizational citizenship behavior was sportsmanship.

In agreement with the present study results, the results Shrestha, \& Subedi, (2020) who clarified that the highest perceived organizational citizenship behavior was courtesy.

On the other hand, a study performed by Ozluk \& Baykal, (2020) about organizational citizenship behavior among nurses: the influence of organizational trust and job satisfaction reported that the highest organizational citizenship behavior perceived by staff nurses was conscientiousness, while the lowest organizational citizenship behavior perceived by nurses was courtesy .

Concerning staff nurses' perception level of organizational citizenship 


\section{Profession}

behaviors.The results showed that marketing dimension was nearly two thirds of staff nurses organizational support.

$(63.3 \%)$ of the staff nurses had a high level of total organizational citizenship behaviors.

In agreement with this study, Meniado, (2021) conducted a study about "Organizational citizenship behavior and emotional intelligence of teachers in Saudi Arabia" and mentioned that nurses had a high level of organizational citizenship behaviors. Results of this study contradicted with a study performed by Mohamed, ElFattah, Abd El-Hamid, \& Mohamed, (2018) to explore the relationship between quality of work-life and organizational citizenship behavior among nurses and showed that a minority $(10 \%)$ of the study participants had a high level of organizational citizenship behavior. While the majority of them had a low level of organizational citizenship behaviors.

This contradiction could be attributed to difference in settings.

For total mean and standard deviation of adherence to internal marketing. The present study showed that the highest internal marketing dimension was job description. While the lowest internal khlif Alshura, Al-Hawary, Al-Syasneh, \& Alhajri, (2020), who studied the influence of internal marketing practices on the employees' intention to leave. It was indicated that employees of private hospitals in Amman evaluated rewards and motivations, internal communication, supervisor support, training programs as the important (highest level).

Concerning staff nurses' perception of utilization of internal marketing of nursing profession. The study study revealed that more than half of nurses (57.2\%) perceived a high level of utilization of internal marketing elements in Menoufia University Hospitals.

The result of the study in agreement with Jahan, \& Allaymoun, (2020) who studied the effect of training, motivation and internal communication on the performance of employees . It was clarified that nurses highly believed that internal marketing practices were contributing to better employee's performance.

On the other hand, a study performed by Gomaa Ragab, \& Mohamed Ali 


\section{Profession}

Saleh, (2020) about formulation of an internal marketing strategy to improve nurses' work engagement demonstrated that about two-thirds of staff nurses reported that internal marketing practices were not effectively applied in health organizations.

This could be attributed to differences in nurses' population.

Concerning the relationship between organizational citizenship behavior and internal marketing of nursing. The present study revealed that there was a significant positive correlation between organizational citizenship behavior and total internal marketing.

In agreement with the present study result, the result of a study performed by Thomas \& Rodrigues (2020) about "Internal marketing and brand promise delivery of Indian public sector banks " clarified that internal marketing practices had a significant effect on organizational citizenship behavior.

Besides, Akbari, Hooshmand \& Aletaha (2019) studied "Internal marketing and the internal customers' citizenship behavior in higher education". It was revealed that there was a positive effect of internal marketing on internal customers' organizational citizenship behavior.
Consistently, this result agreed with Ali, Sleem \& EL-shaer (2017) who conducted a study about "Internal marketing and organizational citizenship behavior: A comparative study in Mansoura general hospital". It was revealed that there was a statistically significant relationship between internal marketing and organizational citizenship behavior.

Simultaneously, Yildiz (2016) studied "The effect of internal marketing on organizational citizenship behavior of academic staff in higher educational institutions", and showed a statistically significant positive effect of internal marketing on organizational citizenship behavior.

In addition, the study performed by Ishaque \& Shahzad (2016) about "The impact of internal marketing on employee behaviors: mediating role of employee job satisfaction". It was revealed that there is a positive significant relationship between internal marketing and organizational citizenship behavior.

Regarding the correlation between organizational citizenship behavior dimensions and internal marketing dimensions of the nursing profession. The present study revealed that there 


\section{Profession}

was a significant positive correlation between organizational citizenship behavior with job description, fair reward, supervisor support, and empowerment.

The present study revealed a significant positive correlation between organizational citizenship behavior and job description, this study result is in agreement with the result of Santoso, Asbari, Siswanto, \& Fahmi (2020) who conducted a study about "The role of job satisfaction and organizational citizenship behavior on performance " and concluded that job satisfaction and organizational citizenship behavior have a positive and significant effect on employees' performance. Besides, the job description has a positive and significant effect on organizational citizenship behavior.

The present study revealed a significant positive correlation between organizational citizenship behavior and fair reward. This study result is in agreement with the result of Sheeraz, Ahmad, Ishaq, \& Nor (2020) who conducted a study about "Moderating role of leader-member exchange between the relationship of organizational justice and organizational citizenship behavior "and revealed that distributive justice and procedural justice are related to altruism, courtesy, and civic virtues, while interactional justice is only correlated with courtesy.

The present study revealed a significant positive correlation between organizational citizenship behavior and supervisor support. This study result is in agreement with the result of Motalebi \& Marsap (2020) who conducted a study about "The role of job satisfaction, and organizational commitment as a determinant of organizational citizenship behavior among the workers of welfare organization "and showed that the a significant positive relationship between the total score of job satisfaction and dimensions of physical condition leadership style with organizational citizenship behavior, showed that high score in these variables is associated with a high score in organizational citizenship behavior.

Consistently, this study agreed with Kose, Dasdemir, Yurdakul Erol \& Yildirim (2019) who conducted a study about "Factors affecting administrative and organizational success in the turkey's forestry "and examined the association between superiors and subordinates in organizations. It was clarified that the degree of employees' 


\section{Profession}

openness to communicate with their superiors is significantly correlated with organizational citizenship behavior.

The results of this study were similar to Sheeraz, Ahmad, Ishaq \& Nor (2020) who studied "Moderating role of leader-member exchange between the relationship of organizational justice and organizational citizenship behavior". Where it was found that distributive justice and procedural justice are related to altruism, courtesy, and civic virtues, while interactional justice is only correlated with courtesy. Additionally, leadermember exchange (LMX) was found to be a significant moderator in the relationship between organizational justice and organizational citizenship behavior.

The present study revealed a significant positive correlation between organizational citizenship behavior and empowerment. This study result is in agreement with the result of Adekoya, Jimoh, Okorie, \& Olajide, (2019); AlMa'aita, \& Abdullah, (2019) who conducted a study about "Significance of employee engagement and individual well-being on organizational performance in Nigeria "and revealed that adequately empowered, employees are positioned to make timely decisions, increase innovation, productivity, and bottom-line performance which increases commitment to the organization while responding to any changes in the environment.

Besides, Abdulrab, Zumrah, Alwaheeb, Al-Mamary \& Al-Tahitah (2020) studied "Impact of transformational leadership and psychological empowerment on organizational citizenship behavior "and mentioned that psychological empowerment significantly influenced the participants' organizational citizenship behavior (psychological empowerment is positively related to organizational citizenship behavior). This result could be explained by the psychological empowerment theory which argued that employees who are highly selfempowered are capable of being actively oriented towards their work and their performance can be beyond their normal and expected one.

Simultaneously, Helmy, Adawiyah \& Banani (2019) studied "Linking psychological empowerment, knowledge sharing, and employees' innovative behavior in SMEs "and showed that psychological empowerment has a significant 


\section{Profession}

influence on organizational citizenship behavior. For instance, found that the influence of psychological empowerment on organizational citizenship behavior is significant.

Similarly, the study conducted by Abdulrab, Zumrah, Almaamari, AlTahitah, Isaac \& Ameen (2018) about "The role of psychological empowerment as a mediating variable between perceived organizational support and organizational citizenship behavior in Malaysian higher education institutions "and demonstrated that psychological empowerment has a positive impact on organizational citizenship behavior. This finding also implies that employees who are psychologically empowered are more likely to exhibit citizenship behavior.

In disagreement with the present study, results of Asgari, Mezginejad, \& Taherpour (2020) who studied "The role of leadership styles in organizational citizenship behavior through the mediation of perceived organizational support and job satisfaction", and mentioned that a highly significant positive correlation was found between organizational support and organizational citizenship.
On the other hand, Khan\& Ghufran (2018) studied "The mediating role of perceived organizational support between qualitative job insecurity, organizational citizenship behavior, and job performance".It was indicated that the effect of job insecurity on OCB and job performance was completely mediated by perceived organizational support.

On the contrary, Norris \& Porter (2021) who studied "The influence of spirituality in the workplace and perceived organizational support on organizational citizenship behaviors for strategic success", clarified that perceived organizational support exerts influence on civic virtue, which is an organizationally directed organizational citizenship behavior.

Furthermore, a study conducted by Anjum and Naqvi, (2012) about the impact of perceived supervisor support on organizational citizenship behavior and explained that employees with lower ranks in the organization perceive themselves as receiving less support from their supervisors, they also put less trust in their supervisors, which affect their willingness to demonstrate organizational citizenship behavior. 


\section{Profession}

On the opposite side, Kloutsiniotis \& Mihail (2020) who conducted a study about "The effects of high performance work systems in employees' serviceoriented OCB "revealed that both "justice" and "service" climates create favorable reciprocal exchanges between employees and employers, leading to work engaged employees. In turn, these engaged employees reciprocate by seeking for better solutions to the everyday problems, by showing support to their colleagues, by generating creative ideas and solutions, and finally by exhibiting "service-oriented OCB" .

In disagreement with the present study, results of Zaghini, Biagioli, Prandi, Fida \& Sili (2015) who performed a study about "Nurses and organizational citizenship behavior: contribution to the Italian validation of the podsakoff et al. Scale "and demonstrated that Nurses' gender and professional training were positively correlated with organizational citizenship behavior.

\section{CONCLUSION}

In the light of the present study, it can be concluded that nearly two-thirds of the staff nurses had a high level of organizational citizenship behaviors. More than half of staff nurses reported a high level of utilization of internal marketing elements. Additionally, there is a highly statistically significant positive correlation between organizational citizenship behaviors and total internal marketing at Menoufia University hospitals at Shebin El-Kom.

\section{Recommendations}

Based on the findings of this study, the following recommendations are proposed:

1. Overall, internal marketing must be an essential part of the corporation's marketing plan; and must be integrated into the overall marketing strategy of any organization.From the practitioner's perspective, it is suggested that corporations should adopt the concept of internal marketing that focuses on providing a set of activities to increase the levels of organizational citizenship behavior.

2. Menoufia University Hospitals should provide more care to internal marketing activities, and direct more organizations' resources and capabilities towards benefiting their employee as much as possible.

3. Development of informal mechanisms such as participatory culture, a pivotal element for 


\section{Profession}

strengthening citizenship behavior,

altruism, consciousness, sportsmanship, and courtesy in their efforts at the workplace.

\section{References:}

Abdulmuhsin, A. A., Zaker, R. A., \& Asad, M. M. (2021). How exploitative leadership influences on knowledge management processes: the moderating role of organisational citizenship behaviour. International Journal of Organizational Analysis. 29(3), 529-561.

Abdulrab, M., Zumrah, A., Almaamari, Q., Al-Tahitah, A., Isaac, O., \& Ameen, A. (2018). The role of psychological empowerment as a mediating variable between perceived organizational support and organizational citizenship behaviour in Malaysian higher education institutions. International Journal of Management and Human Science (IJMHS), 2(3), 114.

Abdulrab, M., Zumrah, A., Alwaheeb, M., Al-Mamary, Y., \& Al-Tahitah, A. (2020). The Impact of Transformational Leadership and Psychological Empowerment on Organizational Citizenship Behaviors: A PLS-SEM
Approach. Journal of Critical

Reviews, 7(9), 908-917. Abo Soliman, A., El-sayed, N., Ibrahim, S., Inany, E. \& Ibrahim, R. (2020). Development of an Internal Marketing Strategy for Faculty of Nursing at Port Said University. Port Said Scientific Journal of Nursing, 7(2), 97-113. Adekoya, D., Jimoh, I., Okorie, G., \& Olajide, M. (2019). Significance of employee engagement and individual well-being on organizational performance in Nigeria. International Journal of Science and Management Studies, 2(5), 35-47.

Akbari, M., Hooshmand, M., \& Aletaha, S. (2019). Internal Marketing and the Internal Customers' Citizenship Behavior in Higher Education. International Journal of Schooling, 1(3), 15-28. Ali, S. (2017): Internal Marketing and Organizational Citizenship Behavior: A comparative study. Department of Nursing Administration, Faculty of Nursing, Mansoura University; 11(11), 1-8.

Ali, S., Sleem, W., \& EL-shaer, A. (2017). Internal Marketing and Organizational Citizenship 


\section{Profession}

Behavior a comparative study in Mansoura. Mansoura Nursing Journal, 4(1), 243-253.

Anjum, A., \& Naqvi, G. (2012). Impact of perceived supervisor support on organizational citizenship behavior: mediating role of trust. In The Asian conference on Psychology \& the behavioral, Osaka, Japan, pp (249-261).

Asgari, A., Mezginejad, S., \& Taherpour, F. (2020). The role of leadership styles in organizational citizenship behavior through the mediation of perceived organizational support and job satisfaction. Innovar, 30(75), 8798.

Boonparn, C., Rurkwararuk, W., Pooncharoen, N., \& Leamprecha, N. (2020). The Relationship of Schwartz's Basic Individual Values with Internal Marketing, Brand Citizenship Behaviour, and Organizational Citizenship Behaviour: A Case Study of CallCentre Staff of Credit Card Issuers in Thailand. Humanities, Arts and Social Sciences Studies) (Former name silpakorn university journal of social sciences, humanities and arts), 20(2), 399-426.
Chamisa, S., Mjoli, T., \& Mhlanga, T. (2020). Psychological capital and organisational citizenship behaviour in selected public hospitals in the Eastern Cape Province of South Africa.SA Journal of Human Resource Management, 18(0), 12-18.

Da Silva, M., Valente, M., Petroli, A., Detoni, D., \& Milan, G. (2020). Perceived quality of built environment, service, satisfaction and value in use, in the context of residential buildings. Journal of Facilities Management. 18 (4), 451-

468. https://doi.org/10.1108/JFM-

05-2020-0032.

De Bruin, L., Roberts-Lombard, M., \& De Meyer-Heydenrych, C. (2020). Internal marketing, service quality and perceived customer satisfaction. Journal of Islamic Marketing. 12 (1), 199-224.

Gabbianelli, L., \& Pencarelli, T. (2021). Exploring some marketing practices in management consulting firms: evidence from small service firms in Italy. The TQM Journal. Vol. ahead-of-print No. ahead-of print. https://doi.org/10.1108/TQM $\underline{-12-2019-0308}$ 


\section{Profession}

Gomaa Ragab, O., \& Mohamed Ali Saleh, N. (2020). Formulation of Internal Marketing Strategy to Improve Nurses' Work Engagement. Assiut Scientific Nursing Journal, 8(20), 249-256.

Griffin, R., Phillips, J., Gully, S., Creed, A., Gribble, L., \& Watson, M. (2020). Organizational Behavior: Engaging People and Organizations. Cengage AU. $1^{\text {st }}$ edition, AU. $1^{\text {st }}$ edition, chapter 1 , pp (512).

Helmy, I., Adawiyah, W., \& Banani, A. (2019). Linking psychological empowerment, knowledge sharing, and employees' innovative behavior in SMEs. The Journal of Behavioral Science, 14(2), 66-79.

Ishaque, A., \& Shahzad, K. (2016). Impact of internal marketing on employee behaviors: Mediating role of employee job satisfaction. Abasyn University Journal of Social Sciences, 9(1), 233-250.

Jahan, N., \&Allaymoun, M. (2020). The Effect of Training, Motivation and Internal Communication on the Performance of Employees at Jordanian Islamic Banks. Journal of Business and Management Studies, 2(2), 16-23.
Kasekende, F., Nasiima, S., \& Otengei, S. O. (2020). Strategic human resource practices, emotional exhaustion and OCB: the mediator role of person-organization fit. Journal of Organizational Effectiveness: People and Performance. 7 (3), 275-295.

Khan, R., \& Ghufran, H. (2018). The mediating role of perceived organizational support between qualitative job insecurity, organizational citizenship behavior and job performance. J Entrepren Organiz Manag, 7(228), 2.

Kloutsiniotis, P., \& Mihail, D. (2020). The effects of high performance work systems in employees' service-oriented OCB. International Journal of Hospitality Management, 7(3) 90, 102610.

Köse, M., Daşdemir, I., Yurdakul Erol, S., \& Yildirim, H. (2019). Factors affecting administrative and organizational success in the turkey's forestry. Applied ecology and environmental research, 17(4), 8713-8735.

Kryscynski, D., Coff, R., \& Campbell, B. (2021). Charting a path between firm-specific incentives and human capital-based competitive 


\section{Profession}

advantage. Strategic Management Journal, 42(2), 386-412.

Meniado, J. (2021). Organizational Citizenship Behavior and Emotional Intelligence of EFL Teachers in Saudi Arabia: Implications to Teaching Performance and Institutional Effectiveness. Arab World English Journal, 11 (4)3-14.

Mohamed, H., El-Fattah, A., Abd ElHamid, M., \& Mohamed, W. (2018). The Relationship between Quality of Work Life and Organizational Citizenship

Behavior among Nurses at ElMansoura Health Insurance Hospital. Zagazig Nursing Journal, 14(1), 148-159.

Mohammad, A., Saleem khlif Alshura, M., Al-Hawary, S., Al-Syasneh, M., \& Alhajri, T., (2020). The influence of Internal Marketing Practices on the employees' intention to leave: A study of the private hospitals in Jordan. International Journal of Advanced Science and Technology, 29(5), 1174-1189.

Motalebi, P., \& Marşap, A. (2020). The role of Job satisfaction, and Organizational commitment as a determinant of organizational citizenship behavior among the workers of welfare organization. SSRG International Journal of Economics and Management Studies (SSRGIJEMS), 7(1), 102-112.

Norris, S., \& Porter, T. (2021). The influence of spirituality in the workplace and perceived organizational support on organizational citizenship behaviors for strategic success. In Research Anthology on Religious Impacts on Society (pp. 1-25). IGI Global.

Ozluk,B., \&Baykal U. (2020). Organizational Citizenship Behavior among Nurses: The Influence of Organizational Trust and Job Satisfaction. Florence Nightingale Journal of Nursing, 28(3), 333-340.

Santoso, P., Asbari, M., Siswanto, E., \& Fahmi, K. (2020). The Role of Job Satisfaction and Organizational Citizenship Behavior on Performance: Evidence from Indonesian Teachers. International Journal of Social and Management Studies, 1(1), 22-31

Santoso, P., Asbari, M., Siswanto, E., \& Fahmi, K. (2020). The Role of Job Satisfaction and Organizational 


\section{Profession}

Citizenship Behavior on

Performance: Evidence from

Indonesian Teachers. International

Journal of Social and Management

Studies, 1(1), 22-31.

Sheeraz, M., Ahmad, U., Ishaq, M., \&

Nor, K. (2020). about Moderating

role of leader-member exchange

between the relationship of

organizational justice and

organizational citizenship

behavior. Pakistan Journal of

Commerce and Social Sciences

(PJCSS), 14(3), 635-660.

Shrestha, M., \& Subedi, D. (2020).

Organizational

Citizenship

Behavior among Teachers of

Nepal: Did Locale Contribute it's

in School Settings? American

Journal of Economics and Business

Management, 3(1), 1-23.

Thomas, B., \& Rodrigues, A. (2020).

Internal Marketing and Brand

Promise Delivery of Indian Public

Sector Banks: A Causal

Relationship Analysis. Indian

Journal of Marketing, 50(10-11), 40-56.

Titisari, P., Afandi, M., \& Lukiyanto,
K. (2020). Organizational

citizenship behavior: Antecedents and the effect on employee performance at a state treasury office in Indonesia.PalArch's Journal of Archaeology of Egypt/Egyptology, 17(7), 92709280.

Yeum, M., Wee, K., \& Bang, W. (2020). The Effect of Internal Marketing on Competitive Advantage as Organizational Coaching-The Mediating Effect of Service Innovation. Journal of System and Management Sciences, $10(1), 62-71$.

Yildiz \& Suleyman (2016): The Effect of Internal Marketing on Organizational Citizenship Behavior of Academic Staff in Higher Educational Institutions. Universal Journal of Educational Research; 4(5), 1122-1128. .

Zaghini, F., Biagioli, V., Prandi, C., Fida, R., \& Sili, A. (2015). Nurses and organizational citizenship behavior: contribution to the Italian validation of the Podsakoff et al. scale. La Medicina del lavoro, 106(6), 460-471. 